\title{
EFFECT OF ETHANOL EXTRACT AND ETHYLACETATE FRACTION OF ARECA SEEDS (Areca catechu L.) ON CHANGES IN WORM INTENSITY IN MICE (Mus musculus) GIVEN PER-ORAL INFECTIOUS TRICHURIS MURIS EGGS
}

\author{
Endy Juli Anto',2), Aznan Lelo3), Syafruddin Ilyas4), Marline Nainggolan5) \\ 1)Post Graduate Student of Doctoral Program, Faculty of Medicine, \\ Universitas Sumatera Utara \\ 2)Faculty of Medicine, Universitas Methodist Indonesia \\ 3)Faculty of Medicine, Universitas Sumatera Utara \\ 4)Faculty of Mathematics and Natural Science, Universitas Sumatera Utara \\ 5)Faculty of Pharmacy, Universitas Sumatera Utara
}

\begin{abstract}
Background: The intestinal parasitic nematode is among the most common causes of human infectious disease worldwide.The mouse whipworm Trichuris muris has been extensively used as a model to study human whipworm infection. Areca seeds (A. catechu L.) have long been known as antihelmintic. This study aimed to examine the effect of ethanol extract and ethylacetate fraction of areca seeds (Areca Catechu L.) on changes in worm intensity in mice (Mus Musculus) given per-oral infectious Trichuris Muris eggs.

Subjects and Method: This was experiment study with post-test only control group design conducted at the Faculty of Mathematics and Natural Science Laboratory, Universitas Sumatra Utara, Medan. A sample of 10 male micewas randomly assigned to 7 group: (1) negative control (normal);(2) induction of 200 T. Muris infective eggs (positive control); (3) induction of 200 T. Muris infective eggs and ethanol ekstract areca seeds p.o. (per oral) $100 \mathrm{mg} / \mathrm{kgbw}$;(4) induction of $200 \mathrm{~T}$. Muris infective eggs and ethanol ekstract areca seeds, p.o. $150 \mathrm{mg} / \mathrm{kgbw} ;(5)$ induction of $200 \mathrm{~T}$. Muris infective eggs and ethylacetate fraction of areca seeds p.o. $100 \mathrm{mg} / \mathrm{kgbw}$;(6) induction of $200 \mathrm{~T}$. Muris infective eggs and ethylacetate fraction of areca seeds, p.o. 150 $\mathrm{mg} / \mathrm{kgbw}$; (7) induction of 200 T. Muris infective eggs and Albendazol p.o. $1 \mathrm{mg} / 20 \mathrm{~g}$. Intensity was described in Mean and SD.

Results: Intensity of worm T. murisafter days-37 was as followed. In positive control or group 2, there were 13 worms (Mean=1.30; $\mathrm{SD}=1.41$ ). In group 3, there were 2 worms (Mean=0.20; $\mathrm{SD}=0.42)$. In group 4, there were no worms. In group 5 , there were 8 worms (Mean $=0.80 ; \mathrm{SD}=0.91)$. In group 6 , there were 22 worms $(M e a n=2.20$; $\mathrm{SD}=2.34$ ). In group 7 , there were 9 worms (Mean=0.90; $\mathrm{SD}=1.10)$. The pairwise statistical significance ( $p$ values) was as followed. Groups $1-2(p=0.005)$, groups $2-3(p=$ $0.040)$, groups $2-4(p=0.005)$, groups $3-6(p=0.004)$, groups $4-5(p=0.013)$, groups $4-6$ $(\mathrm{p}=0.001)$, groups $4-7(\mathrm{p}=0.013)$.The remaining pairwise Mean differences were statistically non-significant.
\end{abstract}

Conclusion: Ethanol extract of areca seeds 150mg / kgbw is more effective as an antihelmintic than the ethylacetate fraction of areca seeds and albendazole.

Keywords: areca seeds, Areca Catechu L., worm, mice, Mus Musculus, Trichuris Muris.

Correspondence:

Endy Juli Anto. Post Graduate Student of Doctoral Program, Faculty of Medicine, Universitas Sumatera Utara, Medan, North Sumatera. Email: Mobile: +6282367667575 